\title{
NATURAL LEVELS OF LEAD-210, POLONIUM-210 AND RADIUM-226 IN HUMANS AND BIOTA OF THE ARCTIC
}

\author{
By DR. RICHARD B. HOLTZMAN \\ Radiological Physics Division, Argonne National Laboratory
}

\begin{abstract}
$\mathrm{R}^{\mathrm{B}}$ ELATIVELY high concentrations of some fission products in humans and biota from Lapland and Alaska have been reported ${ }^{1-5}$. These have been attributed to the continual accumulation of these products on the long-lived, slow-growing Arctic lichens and sedges. Such plants are an important source of forage for reindeer and caribou, the meat of which, in turn, constitutes a substantial portion of the diets of Laplanders and Eskimos. These high levels of fall-out suggest, together with the proposed mechanism of uptake and the similarities to strontium-90 in atmospheric distribution ${ }^{6}$ and biochemistry, that in Arctic biota the naturally occurring airborne nuclides lead-210 and its decay product, polonium-210, may also be present in high concentration. This phenomenon has, in fact, been reported by $\mathrm{me}^{7}$ and more recently by Hills.

These naturally occurring 'fall-out' activities are of special interest in studies of aerosol precipitation mechan. isms because their levels are independent of bomb tests and consequently they have been constant over the years. Because of this constancy and the high energy of the particles emitted by the lead-210 series (a $5 \cdot 3-\mathrm{MeV}$ $\alpha$-particle from polonium-210 and a $0 \cdot 4-\mathrm{MeV}$ [average energy] $\beta$-particle from bismuth-210 compared with $\beta$-rays with average energies of $0.4 \mathrm{MeV}$ from caesium-137 and $1 \cdot 1 \mathrm{MeV}$ from strontium-90 [yttrium-90 $\left.]^{9}\right)$, the radiation dose to Arctic biota from this source may be quite significant relative to that from artificial ones.
\end{abstract}

\section{Samples and Experimental Procedures}

In order to elucidate some of the properties and mechanisms related to the accumulation of the airborne activities, data are presented on the concentrations of ${ }^{210} \mathrm{~Pb},{ }^{210} \mathrm{Po}$ and ${ }^{228} \mathrm{Ra}$ (the long-lived precursor of the ${ }^{210} \mathrm{~Pb}$ ) in specimens of the human food chain from Arctic regions. Specifically, these are: lichens, caribou muscle, bone and rumen (mainly lichens), and human soft tissues (placenta) from Alaska; lichens, fodder (horsetail, Equisetum flaviatile), and reindeer muscle and bone from Finnish Lapland; and lamb bone from Iceland. For comparison, some related plant materials from non-Aretic regions were included-grass from Chicago and lichens from New Hampshire (north-eastern United States). The origins and descriptions of the specimens are presented in Table 1.

The contents of ${ }^{210} \mathrm{~Pb}$ and of ${ }^{210} \mathrm{Po}$ in the samples were determined by a previously described method ${ }^{10}$. The sample was first wet-ashed (1-10 $\mathrm{g}$ of bone, or plant material, or $10-100 \mathrm{~g}$ of dried soft tissue) in concentrated nitric acid until nearly complete dissolution. About $10 \mathrm{ml}$. perchloric acid was added and the mixture heated until it fumed. When the samplo became colourless, concentrated hydrochloric acid was added and it was fumed again. This fuming procedure was repeated three more times to remove residual nitrate, after which the solution was diluted to about $200 \mathrm{ml}$., the $p \mathrm{H}$ adjusted to 0.3 and a portion taken for calcium analysis. The ${ }^{210} \mathrm{Po}$ was then plated on to a silver disk and counted in an internal flow proportional alpha counter. Subsequent replating of the sample after a delay of three or more months to allow grow-in of the ${ }^{210} \mathrm{Po}$ then made it possible to estimate both the ${ }^{210} \mathrm{~Pb}$ and ${ }^{210} \mathrm{Po}$ in the sample at the time of collection.
The ${ }^{226} \mathrm{Ra}$ was determined by the emanation technique of Lucas ${ }^{11}$.

\section{Results and Discussion}

The results are presented in Table 2. In order to facilitate the dosimetry in vivo, the specific sutivities in the soft tissues are given in picocuries per gram of wet tissue. However, because of the difficulties in defining a standard in vivo state for bone ${ }^{12}$, antler and plants, the units are in picocuries per gram ash for bone and antler, and picocuries per gram dry material (at $100^{\circ} \mathrm{C}$ ) for the plants. The overall uncertainties from counting statistics, chemistry, and handling are about 15 per cent, at the 90 per cent confidence level, except where specific values of uncertainties are given.

It was not possible to estimate the initial quantity of polonium in the Alaskan lichen samples because these samples had previously been dry-ashed at $425^{\circ} \mathrm{C}$, a temperature at which this element volatilizes.

Vegetation. The lichens and rumen (composed mainly of lichens) contain specific activities of ${ }^{210} \mathrm{~Pb}$ and ${ }^{210} \mathrm{Po}$ that are very high relative to those in the horsetails and grass. The Alaskan lichens, in turn, contain greater concentrations than those from Finland and New Hampshire. The rumen are lower than the other Alaskan samples, possibly because of contamination from other plant materials and stomach fluids.

Although the concentrations of ${ }^{210} \mathrm{~Pb}$ and ${ }^{210} \mathrm{Po}$ in lichens are high relative to those in the grasses measured here, they are comparable with those in a number of grass samples observed by Hill which range up to 23 pe. ${ }_{210} \mathrm{Po} / \mathrm{g}$ dry ${ }^{13}$. That these latter volues are inconsistent with the relatively small amounts of ${ }^{210} \mathrm{~Pb}-{ }^{210} \mathrm{Po}$ acquired by cattle ${ }^{14,15}$, as compared with those observed in reindeer

\begin{tabular}{|c|c|c|}
\hline Sample & Region & Description \\
\hline $\begin{array}{l}\text { egetation } \\
\text { Lichens }\end{array}$ & Inari, Finland & Species: ('ladonia alpestris, Mareh \\
\hline Horsetails & Inari, Finland & Species: Equisetum flaviatile, sept. \\
\hline Lichens I & $\begin{array}{l}\text { Chariot Site, Cape } \\
\text { Thompson, Alaska }\end{array}$ & $\begin{array}{l}\text { Species: predominantly Cladomia syl- } \\
\text { vatica, June } 1961\end{array}$ \\
\hline Lichens II & $\begin{array}{l}\text { Chariot Site, Cape } \\
\text { Thompson, Alaska }\end{array}$ & $\begin{array}{l}\text { Species: predominantly Cornicularia } \\
\text { divergens. Ach., Alectoria nigricans } \\
\text { Ach. Myl., Alectoria ochrolecua } \\
\text { (Ehrh.) Mass, and small amounts of } \\
\text { other species, June } 1961\end{array}$ \\
\hline Jichens III & $\begin{array}{l}\text { Chariot Site, Cape } \\
\text { Thompson, Alaska }\end{array}$ & Species: same as above, June 1961 \\
\hline Lichens IV & $\begin{array}{l}\text { Lebanon, New } \\
\text { Hampshire }\end{array}$ & Species: Cladonia, July 1965 \\
\hline Grass & Chicago, Illinois & $\begin{array}{l}\text { Species: Kentucky blue grass, May } \\
1962\end{array}$ \\
\hline neindeer & Finland & $\begin{array}{l}\text { 2-4-yr-old animals, female, composite } \\
\text { of ten animals. Musele: shoulder. } \\
\text { Bone, marrow-free. Date of death: } \\
\text { Mareh 14, 1961 }\end{array}$ \\
\hline Caribou I & $\begin{array}{l}\text { Denali Highway, } \\
\text { Alaska }\end{array}$ & $\begin{array}{l}\text { 2-yr-old, male. Muscle: hind quarter. } \\
\text { Bone: femur shaft. Rumen, antler. } \\
\text { Date of death: Dee. } 6,1962\end{array}$ \\
\hline Caribo11 II & $\begin{array}{l}\text { Denali Highway, } \\
\text { Alaska }\end{array}$ & $\begin{array}{l}\text { 3-7-yr-old, male. Muscle: hind } \\
\text { quarter. Bone: femur shaft. } \\
\text { Rumen, antler. Date of death: } \\
\text { Dec. 6, 1962 }\end{array}$ \\
\hline Lamb & Iceland & Commercial lamb obtained in Chicago \\
\hline $\begin{array}{l}\text { Human being, } \\
\text { Subject I }\end{array}$ & $\begin{array}{l}\text { Eskimo placentac } \\
\text { Barrow, Alaska }\end{array}$ & $\begin{array}{l}\text { 23-yr-old; date of parturition: June } \\
1963\end{array}$ \\
\hline Subject II & Barrow, Alaska & $\begin{array}{l}\text { 39-yr-old; date of parturition: June } \\
1963\end{array}$ \\
\hline Subject IrI & Barrow, Alaska & $\begin{array}{l}\text { 16-yr-old; date of parturition: June } \\
7963\end{array}$ \\
\hline
\end{tabular}


Table 2. Lfad-210, Polonium-210 And Radium-226 in Human Berngs

\begin{tabular}{|c|c|c|c|c|}
\hline Sample & Region & ${ }^{210} \mathrm{~Pb}$ & ${ }^{210} \mathrm{Po}$ & ${ }^{226} \mathrm{Ra}$ \\
\hline \multicolumn{5}{|l|}{ Vegetation (pc./g dry) } \\
\hline Lichens & Finland & $4 \cdot 5$ & $13 \cdot 1$ & $0.0035 \pm 0.0010$ \\
\hline Horsetails & Finland & 0.961 & $0 \cdot 24$ & $0.042 \pm 0.005$ \\
\hline Liehens I & Alaska & $11 \cdot 5$ & $3 \cdot 0$ & $0 \cdot 101 \pm 0 \cdot 006$ \\
\hline Lichens II & Alaska & $69 \cdot 6$ & - & $0.415 \pm 0 \cdot 017$ \\
\hline Lichens III & Alaska & $26 \cdot 0$ & $-\overline{-}$ & $0.40 \pm 0.02$ \\
\hline Lichens IV & $\begin{array}{l}\text { New Hamp- } \\
\text { shire }\end{array}$ & $7 \cdot 61$ & $7 \cdot 32$ & - \\
\hline Lichens IV A & $\begin{array}{l}\text { New Hanip- } \\
\text { shire }\end{array}$ & $6 \cdot 95$ & $7 \cdot 50$ & - \\
\hline Rumen, caribou I & Alaska & $5 \cdot 86$ & $14 \cdot 28$ & - \\
\hline Rumen, caribou II & Alaska & $4 \cdot 96$ & $16 \cdot 52$ & - \\
\hline Grass, top & Chicago & $0 \cdot 128$ & 0.053 & - \\
\hline Grass, centre & Chicago & $\begin{array}{l}0 \cdot 230 \\
0 \cdot 717\end{array}$ & $\begin{array}{l}0.064 \\
0 \cdot 431\end{array}$ & - \\
\hline $\begin{array}{l}\text { Grass, lower } \\
\text { Grass, roots }\end{array}$ & $\begin{array}{l}\text { Chicago } \\
\text { Chicago }\end{array}$ & $\begin{array}{l}0.717 \\
0.819\end{array}$ & 0.939 & - \\
\hline \multicolumn{5}{|c|}{ Muscle: reindeer and caribou (pc./g wet) } \\
\hline Reindeer & Finland & 0.015 & $0 \cdot 20$ & $0 \cdot 0003 \pm 0 \cdot 0002$ \\
\hline Caribou & Alaska & $0 \cdot 0060$ & $0 \cdot 222$ & - \\
\hline Caribou & Alaska & $0 \cdot 0083$ & $0 \cdot 163$ & - \\
\hline \multicolumn{5}{|c|}{ Bone or antler: reindeer and caribou (pe./g ash) } \\
\hline Bone, reindeer & Finland & $5 \cdot 00 \pm 0 \cdot 11$ & $6 \cdot 33$ & $1 \cdot 84 \pm 0 \cdot 022$ \\
\hline Bone, caribou I & Alaska & $11 \cdot 0 \pm 0 \cdot 2$ & $15 \cdot 5$ & 二 \\
\hline Bone, caribou II & Alaska & $11 \cdot 1 \pm 0 \cdot 21$ & $14 \cdot 6$ & - \\
\hline Antler, caribou I & Alaska & $7 \cdot 75 \pm 0 \cdot 20$ & $2 \cdot 75$ & $\ldots$ \\
\hline Antler, caribou II & Alaska & $6 \cdot 10 \pm 0 \cdot 25$ & $4 \cdot 63$ & 一 \\
\hline \multicolumn{5}{|l|}{ Bone: lamb (pc/g ash) } \\
\hline Rib & Iccland & $0 \cdot 314 \pm 0 \cdot 019$ & - & $0 \cdot 043 \pm 0 \cdot 007$ \\
\hline Rib & Iceland & $0 \cdot 353 \pm 0.012$ & - & $0 \cdot 104 \pm 0 \cdot 007$ \\
\hline Femur & Iceland & $0.337 \pm 0.013$ & 一 & $0.041 \pm 0.005$ \\
\hline Iliac crest & Iceland & $0.269 \pm 0.013$ & - & $0.099 \pm 0.005$ \\
\hline \multicolumn{5}{|c|}{ Placenta: human being, Eskimo (pc./g wet) } \\
\hline Tissue, subject I & Alaska & $0 \cdot 0037$ & 0.027 & - \\
\hline Tissue, subject II & Alaska & $0 \cdot 0016$ & 0.012 & - \\
\hline Blood, subject II & Alaska & 0.00094 & $0 \cdot 0040$ & - \\
\hline Tissue, subject III & Alaska & $0 \cdot 0010$ & $0 \cdot 0095$ & 一 \\
\hline Blood, subject III & Alaska & 0.00059 & $0 \cdot 0047$ & - \\
\hline Umbilical cord, & Alaska & 0.00072 & $0 \cdot 0040$ & - \\
\hline
\end{tabular}

and caribou (vide infra), may be due to the possibility that the grass measured by Hill is not representative of that consumed by the cattle. These samples were collected in December at which time they may have been growing slowly or have beon dormant, so that, with a constant rate of ${ }^{210} \mathrm{~Pb}$ fall-out, the concentration of this nuclide would increase at a constant rate. On the other hand, during the growing season, the quantity of grass would also have increased, thereby preventing increases in the concentrations of ${ }^{210} \mathrm{~Pb}$. Hill has recently demonstrated this phenomenon by comparing new with old grass from the same locations ${ }^{8}$.

A similar phenomenon has been found in the Chicago grass collected in the spring es shown in Table 2. The average concentration was only $0.3 \mathrm{pc} . / \mathrm{g}$ dry grass, in spite of the fair amount of precipitation $(25 \mathrm{~cm})$ in the 40 days before collection. The data in Table 2 do indicate an age effect, that is the older parts of the plant (or slower growing parts) nearer the ground show higher concentrations of ${ }^{210} \mathrm{~Pb}$. Moreover, correlated with this is an increase in the ${ }^{210} \mathrm{Po} /{ }^{210} \mathrm{~Pb}$ ratio towards 1 . Thus if "Grass, centre" is of recent origin, "Grass, lower" would appear to be about 3 months old.

The levels in reindeer may also be higher than in cattle because of the low ash content of lichens, less than 1 per cent as compared with 5 per cont for grass. Thus, if we assume the mineral requirements of reindeer and cattle to be similar, in order to obtain sufficient mineral the reindeer must consume much more material and consequently more of the radioactive nuclides.

The fact that the ${ }^{210} \mathrm{Po} /{ }^{210} \mathrm{~Pb}$ activity ratios in the lichen and rumen are greater than $l$ is of interest in that in a fall-out mechanism (neglecting othor mechanisms) this ratio, as in the New Hampshire plants and Chicago grass, should be 1 or less, especially as in the atmosphere, at least in the temperate zone, it is approximately $0 \cdot 1$ (ref. 16). The ratio of two or more observed in the lichens implies either a high differential affinity of these plants for ${ }^{210} \mathrm{Po}$ from precipitation or rapid leaching of the ${ }^{210} \mathrm{~Pb}$ from the plants after precipitation. The latter process also implies a non-constant mechanism, that is both nuclides build up and then the ${ }^{210} \mathrm{~Pb}$ is leached preferentially. Continual leaching does not seem likely, since in this case the ${ }^{210} \mathrm{Po}$ could not build up to specific activities greater than those of its parent.
The specific activities of the ${ }^{226} \mathrm{Ra}$ were much lower than those of the ${ }^{210} \mathrm{~Pb}$ and thus the ${ }^{226} \mathrm{Ra}$ does not appear to be a direct source of the ${ }^{210} \mathrm{~Pb}$. The correct specific activity of ${ }^{226} \mathrm{Ra}$ in lichens is eloser to that of the Finnish lichens than to those of the others because this sample was carefully chosen to be dust free, having been collected from an area about 10 miles from the nearest road ${ }^{17}$. Consequently, its ash content was less than 1 per cent of the dry weight as compared with the values of between 5 per cent and 10 per cent for the others. The higher ${ }^{226} \mathrm{Ra}$ activities in the other lichens cen, in the miin, be attributed to contamination with dust.

Animals. Bone from animals, though not a direct source of ${ }^{210} \mathrm{~Pb}$ for human beings, is of interest as, by integriting the intake, it may indicate the average ${ }^{210} \mathrm{~Pb}$ content of the meat. The actual activity measured in muscle, on the other hand, represents the intake only immediately before slaughter (a week or two) and thus is not representative of the long-term average of meat. Investigations on bone may also lead to more subtle and better correlations in nutritional and metabolic studies of these animals because of the much higher specific activities of the nuclides of interest. For example, in reindeer bone the specific setivity is twenty times that in bovine bone ${ }^{14}$, wheress in muscle the respective ratio is only about twice as large ${ }^{10}$.

The 11 pe. ${ }^{210} \mathrm{~Pb} / \mathrm{g}$ ash observed in the Alaskan caribou bone is about twice that in the Finnish bone. This may possibly be due to metabolic differences, but, because they are a vory closely related species, the more probable cause seems to be the reduced dietary intake of this isotope by the semi-domesticated reindeer as a consequence of supplementary fodder feeds low in ${ }^{210} \mathrm{~Pb}$. Moreover, the Finnish lichens, because of their lower concentrations of ${ }^{210} \mathrm{~Pb}$, as indicated in the single sample measured, would supply less of this nuclide than would the Aleskan onos.

An analogous explanation also accounts for the differences in the ${ }^{210} \mathrm{~Pb}$ concentrations between antler and femur of the Alaskan animals, that is, the antler is formed over a short period of time ( 3 months) in the spring ${ }^{18}$ when, owing to the presence of other vegetation, lichens constitute a smaller fraction of the diet than that averaged over the entire year. A comparison of ${ }^{210} \mathrm{~Pb}$ concentrations in femur with those in antler indicates that these concentrations do not vary much from animal to animal from a given region and that the concentration of ${ }^{210} \mathrm{~Pb}$ in femur is about 1.8 times that in antler. Thus it is possible that a few animals, and even their antlers, alone, may well form a representative sample of this population.

The ${ }^{210} \mathrm{Po}$ activities in bone are somewhat higher then those of ${ }^{210} \mathrm{~Pb}$, possibly reflecting the equivalent situation in the lichens and rumen. In antlers, on the other hand, the ${ }^{210} \mathrm{Po}$ activities are lower than those of the ${ }^{210} \mathrm{~Pb}$ which indicates a preferential deposition of the latter. Moreover, these deposits do not seem to be of sufficient age to allow attainment of radioactive equilibrium.

Although the ${ }^{226} \mathrm{Ra}$ activity in bone is much lower than the equivalent ${ }^{210} \mathrm{~Pb}$ and is thus not a major source of this nuclide, it is comparable with DiFerrante's highest values in cattle ${ }^{19}$. The source of this high ${ }^{226} \mathrm{Ra}$ seems to be the lichens, as, although they contain little ${ }^{226} \mathrm{Ra}$ (per g), the ash content (calcium) is also small and consequently the ratio, ${ }^{226} \mathrm{Ra} /$ calcium, is about equal to that observed in bone.

The concentrations of ${ }^{210} \mathrm{~Pb}$ in the muscle of reindeer and. caribou are somewhat higher than those found in cattle, but only by factors of 2-4. However, the Finnish, rather than the Alaskan, animals in this case show the higher activities. This difference may be due to species or feeding habits, but it seems more likely to be seasonal variation. Hanson and Palmer ${ }^{20}$ and Lidén and Svensson ${ }^{21}$ observed very large seasonal variations in the ${ }^{137} \mathrm{Cs}$ content of animals and humans, which the authors attributed to the changes in feeding habits of the animal; they consumed lichens and dormant foliage with their high rates of accumulation versus growth only when necessary--that 
is in the winter. Thus the Finnish animals, slaughtered in the early spring, contained the winter's accumulation of ${ }^{210} \mathrm{~Pb}$, whereas the Alaskan ones, killed in the late autumn, were somewhat depleted of this nuclide.

The ${ }^{210} \mathrm{Po}$ concentrations were comparable in all the animals and an order of magnitude greater than those in steer meat. These high concentrations may ariso from the much greater intake of ${ }^{210} \mathrm{Po}$ by reindeer than by cattle and to the relatively higher ${ }^{210} \mathrm{Po} /{ }^{210} \mathrm{~Pb}$ ratio in the food, it being about $0 \cdot 2$ in grass and 2 in lichens. Osborne has shown that at natural levels in humans the ${ }^{210} \mathrm{Po} /{ }^{210} \mathrm{~Pb}$ ratio in soft tissue may be 3 or more ${ }^{22}$. Thus, in the case of reindeer where the ${ }^{210} \mathrm{Po}$ intake and the ${ }^{210} \mathrm{~Pb}$ concentrations in bone are relatively high, ${ }^{210} \mathrm{Po}$ accumulation in the soft tissues may also be expected to be high.

In contrast to the reindeer and caribou, the concentrations of ${ }^{210} \mathrm{~Pb}$ found in Icelandic sheep show that not all herbivores from this region contain relatively large amounts of these nuclides. In these animals, the ${ }^{210} \mathrm{~Pb}$ and ${ }^{226} \mathrm{Ra}$ concentrations are comparable with those in bovine bone ${ }^{14}$, suggesting that the ${ }^{210} \mathrm{~Pb}$ content in its diet is comparable with that of cattle from the United States. By analogy with Puerto Rico, an oceanic island which probably has lower ${ }^{210} \mathrm{~Pb}$ fall-out rates than do continental regions, and consequently lower ${ }^{210} \mathrm{~Pb}$ concentrations (in humans the concentrations in bone are about 65 por cent of those in residents of continental regions) ${ }^{23}$, the ${ }^{210} \mathrm{~Pb}$ content of the diet of sheep in Iceland would be lower than that of reindeer and caribou even on a similar diet.

While muscle from caribou and reindeer has concentrations of ${ }^{210} \mathrm{~Pb}$ low relative to those in bone, it still constitutes the major source of this nuclide in Lapps and Alaskans. Miettinen et al.$^{2}$ report that, in Finnish Lapland, male roindeer breeders consume about $12.4 \mathrm{~kg} /$ month or $400 \mathrm{~g} /$ day of reindeer meat which, if we use the ${ }^{210} \mathrm{~Pb}$ content for the reindeer muscle $(0.2 \mathrm{pc} . / \mathrm{g})$, implies that these people ingest about $8 \mathrm{pc}$./day. The rate is more than four times the mid-western United States rate of about $1.8 \mathrm{pc} . /$ day $^{10}$.

Other Lapps listed by Miettinen et al. consume from 1.2 to $12.0 \mathrm{~kg} / \mathrm{month}$ which represents about $0.8-5 \mathrm{pc}$. $/$ day from meat alone. If the other food consumed is comparable with that from the United States, even these other Lapps ingest about twice that of the United States residents.

Similar dietary information on Alaskans ${ }^{4}$ shows that in certain regions the average consumption of reindeer and/ or caribou meat ranges up to $900 \mathrm{~g} /$ day (Anaktuvuk Pass Eskimos), so that even though the ${ }^{210} \mathrm{~Pb}$ levels measured in the Alaskan caribou are lower than in the Finnish reindeer, the total intake by Alaskans is comparable with that of the Lapps.

Eskimo bone has not been measured here because of the difficulties in obtaining it. However, some comparison may be made from data on soft tissues in Table 2 from residents of Barrow, Alaska, who consume about $170 \mathrm{~g} /$ day' of caribou or reindeer meat. The values for placenta appear to range in wet tissue from 0.001 to $0.005 \mathrm{pc} .{ }^{210} \mathrm{~Pb} / \mathrm{g}$ and from 0.009 to $0.030 \mathrm{pc} .{ }^{210} \mathrm{Po} / \mathrm{g}$. These concentrations for both nuclides are somewhat higher than those for soft tissue found by Osborne $e^{22}$ and by $\mathrm{me}^{10}$.

Although the ${ }^{210} \mathrm{~Pb}$ concentrations in placentel tissue in Arctic residents are somewhat higher than in the soft tissues of non-Arctic residents, the ${ }^{210} \mathrm{Po}$ ingestion in the former group may be extremely high, $40-160 \mathrm{pc}$./day. These levels are 20-100 times those of others if we assume a concentration of $0.2 \mathrm{pc}$./g wet meat and a consumption of about 200-800 g/day ${ }^{2,4}$. Thus, the steady-state amount of ${ }^{210} \mathrm{Po}$ in the body acquired from a constant daily intake may be estimated from equation 48 of the report ${ }^{\circ}$ issued by the International Commission on Radiological Protection, derived from the exponential model for the uptake and excretion of nuclides :

$$
\frac{m C}{I}=\frac{T_{e} f}{0 \cdot 693}
$$

where $m$ is the mass of the body, $C$ is the concentration of the nuclide of interest, $I$ is the daily intake, $T_{e}$ is the effective half-life of the nuclide in the body, and $f$ is the fraction of the nuclide going from the food to the body.

If for ${ }^{210} \mathrm{Po} T_{e}=25$ days and $f=0 \cdot 06$, then the portion of the whole-body content from this source is $2 \cdot 2$ times the daily intake. In the case of interest it is $90-350 \mathrm{pc}$. The ${ }^{210} \mathrm{Po}$, which deposits mainly in the soft tissues, is then quite significant, being 125-350 per cent of that in nonArctic populations in whom the ${ }^{210}$ Po content of the soft tissues is estimated to be about 230 pc. (ref. 24). In bone, the ${ }^{210} \mathrm{Po}$ levels from this source would be increased only a few per cent.

The large increase in levels of ${ }^{210} \mathrm{Po}$ is indicated in the data on human placentae which show that, if the metabolic properties of this nuclide in this tissue are assumed to be similar to those in the lung, skeletal muscle or spleen, Arctic dwellers accumulate six to ten times that found in the soft tissues of Britons ${ }^{22}$. The concentrations in the placentae are as much as three times those found in the liver and kidney of people living outside the Arctic. In addition to this comparison, it should be noted that because the placentae studied were obtained in the summer, they probably represent only the lower limit of concentrations that could be found. These tissues were formed during the winter when the main food was caribou killed in the autumn, which after summer forage (little intake of lichens) are known to contain minimum amounts of ${ }^{137} \mathrm{Cs}$ (refs. 20 and 21 ), and thus probably also of ${ }^{210} \mathrm{~Pb}$ and ${ }^{210} \mathrm{Po}$.

Dosimetry. In the mid-western United States, ${ }^{210} \mathrm{Po}$ from the deposited ${ }^{210} \mathrm{~Pb}$ has been shown to contribute 20 per cent of the total skeletal dose in the human (50 per cent of that from internally deposited nuclides ${ }^{10}$. The data presented here show that in the Arctic these nuclides exist in substantially greater concentrations in reindeer and caribou than in mid-western cattle and in Icelandic sheep. The consequent intake by humans consuming the meat from the Aretic animals is also large, but by a smaller fraction than previously estimated ${ }^{17}$. (C. R. Hill, in a personal communication, has pointed out that the previously reported values of ${ }^{210} \mathrm{~Pb}$ in reindeer muscle were mainly values of ${ }^{210} \mathrm{Po}$.) The data on the Eskimo placentae give some support to this conclusion, but to 8 lesser extent than Hill's data on the rib bone of Canadian Eskimos. In two cases, high activities of ${ }^{210} \mathrm{Po}$ were observed and probably also of ${ }^{210} \mathrm{~Pb}$, as in bone the ${ }^{210} \mathrm{Po} /{ }^{210} \mathrm{~Pb}$ ratio is near unity, at least in people living outside the Aretic region ${ }^{10,22}$. The result of $2 \cdot 3$ pe. ${ }^{210} \mathrm{Po} / \mathrm{g}$ ash found by $\mathrm{Hill}^{25}$ is more than fifteen times grester than the average for people living in the mid-western United States. (Note added in proof. Since submission of this paper, Hill has reported this in more detail. The values measured were actually ${ }^{210} \mathrm{~Pb}$ (Nature, 208,$\left.423 ; 1965\right)$.)

These findings imply that in users of reindeer and caribou meat the total radiation dose rates from the natural sources are somewhat higher than in non-users. The total skeletal rates to people living in the mid-western United States are about $100 \mathrm{mrad} / \mathrm{yr}^{26}$. If the relative biological effectiveness for $\alpha$-particles is assumed to be 4 , the effective dose is about $130 \mathrm{mrem} / \mathrm{yr}$, of which about 20 per cent is contributed by the ${ }^{210} \mathrm{~Pb}-{ }^{210} \mathrm{Po}$ pair. Thus, populations ingesting four times the average level of ${ }^{210} \mathrm{~Pb}$ would experience dose rates about 30 per cent greater than those living in the mid-western United States. (It should be noted that in this latter group orly about half is acquired by ingestion, the other half coming from inhalation, the absolute amount of which would be about the same in Arctic residents ${ }^{10}$. Thus, quadrupling the ingestion rate would increase the total amount only by a factor of $2 \cdot 5$.) In the case of Hill's Eskimo, the bone would experience a total dose of more than $400 \mathrm{mrem} / \mathrm{yr}$, three times that of people living in the mid-western United States. The ${ }^{210} \mathrm{~Pb}-{ }^{210} \mathrm{Po}$ dose alone may then be comparable with the high fall-out doses from bombs as measured in the Arctic. 
Although data from Arctic placentae show a dramatic incroase in ${ }^{210} \mathrm{Po}$ levels over those in other tissues from non-Aretic residents, the actual increase in dose at natural levels is small (about 10 per cent), based on the assumptions that the normal level is $100 \mathrm{mrem} / \mathrm{yr}$, that 0.01 pc. ${ }^{210} \mathrm{Po} / \mathrm{g}$ wet tissue produces a dose of $1 \mathrm{mrad} / \mathrm{y}^{\prime} \mathrm{r}$, and that the relative biological effectiveness for $\alpha$-particles is 4 . (With the usually assumed relative biological effective. ness of 10 , the dose would be increased to about $130 \mathrm{mrem}$.) However, these numbers may be significant relative to the much larger values in bone because, for instance, the radiation effects to soft tissue may be greater than to bone, or the relative biological effectiveness at low dose rates may be much different than that used here.

\section{Conclusion}

Further investigations of this type, together with the epidemiology, would provide information of value in assessing the effects of low-level radiation on human and animal populations. (The reindeer and caribou are exposed to skeletal doses of 1-10 rems/yr (relative biological effectiveness $=4$ ) which is fifty times that of cattle and 500 times that of humans.) Natural 'fall-out' is also of particular use in tracing food chains and in studying the metabolic properties of the nuclides and elements involved. Moreover, similar studies of this type appear to be feasible elsewhere, as the high levels of natural (and artificial) 'fall-out' are, with our present knowledge, only by chance characteristic of the Arctic, that is, the lichen is a slowgrowing plant eaten only by reindeer and caribou which, in turn, form a substantial part of the human diet. Similar conditions might obtain in other regions, such as deserts, where vegetation, for lack of water, may grow only slowly. This phenomenon is indicated in Hill's data on camel bone ${ }^{8}$ and in DiFerrante's ox bone ${ }^{14}$, in which the specimens with the higher activities came from the more arid regions.

I thank the many people who contributed many ideas and specimens to this research, particularly R. A. Dudley of the International Atomic Energy Agency, J. N. Wolfe and J. J. Davis of the U.S. Atomic Energy Commission, J. K. Miettinen of the University of Helsinki, L. A. Viereck of the State of Alaska Department of Fish and Game, and R. T. Light of the U.S. Public Health Service. Special thanks are due to L. D. Marinelli and J. E. Rose for their help and encouragement. The work was performed under the auspices of the U.S. Atomic Energy Commission.

${ }^{1}$ Lidén, K., Acta Radiol., 56, 237 (1961).

${ }^{2}$ Miettinen, J. K., Jokelainen, A., Roine, P., Lidén, K., Naversten, Y., Bengtsson, G., Häsänen, E., and McCall, R.C., Ann. Acad. Sci. Fenn., A, II, Chemical, 120 (1963).

${ }^{3}$ Palmer, H. E., Hanson, W., Griffin, B. I. and Roesch, W. C., Radioactivity in Man, 527 (Springfield, Ill., Charles C. Thomas, 1965).

${ }^{4}$ Hanson, W. C., Palmer, H. E., and Griffin, B. I., Health Physics, 10, 421 (1964).

${ }^{5}$ Schulert, A. R., Science, 136, 146 (1962).

${ }^{6}$ Lockhardt, jun., L. B., Patterson, jun., R. L., Saunders, jun., A. W., and Black, R. W., Radiol. Hlth. Data, 4, 71 (1963).

${ }^{7}$ Holtzman, R. B., Argonne Nat. Lab. Radiol. Phys. Div. Sum. Rep., ANL $6769,59(1963)$.

${ }^{8}$ Hill, C. R., paper presented at symposium on "Radioactivity in Scandinavia", Denmark (1964).

'International Commission on Radiological Protection, Health Phys., 3, 1 $(1960)$.

${ }^{10}$ Holtzman, R. B., Health Phys., 9, 385 (1963).

${ }^{1}$ Lucas, jun., H. F., Argonne Nat. Lab. Radiol. Phys. Div. Semiann. Rep. $A N L-6297,55$ (1961)

${ }^{12}$ Holtzman, R. B., Health Phys., 8, 315 (1962).

${ }^{13}$ Hill, C. R., Nature, 187, 211 (1960).

${ }^{14}$ DiFerrante, E. R., Argonne Nat. Lab. Semiann. Rep., ANI-6398, 71 (1961).

15 Hill, C. R., and Jaworoski, Z, S., Nature, 180, 353 (1961).

${ }^{16}$ Burton, W. M., and Stewart, N. G., Nature, 186, 584 (1960).

${ }^{17}$ Miettinen, J. K. (personal communication).

${ }^{18}$ Macewen, W., The Growth and Shedding of the Antlers of Deer, 1 (Jackson and Co., Giasgow, 1920).

${ }^{10}$ DiFerrante, E. R., Health Phys.,10, 259 (1964).

${ }^{20}$ Hanson, W. C., and Palmer, H. E., Health Phys, , 11, 1401 (1965).

${ }^{21}$ Lidén, K., and Svensson, G. K., Health Phys, 11, 1393 (1965).

${ }^{22}$ Osborne, R. V., Nature, 199, 295 (1963).

${ }^{28}$ Holtzman, R. B., Health Phys., 11, 477 (1965).

${ }^{24}$ Holtzman, R. B., Health Phys, 10, 763 (1964).

${ }^{25}$ Hill, C. R., Health Phys., 8, 17 (1962).

${ }^{26}$ Dudley, R. A., Low-Level Irradiation, 7 (Amer. Assoc. Advancement of udley, R. A., Low-Level Irradid
Science, Washington, 1959).

\section{OBITUARIES}

\section{Prof. R. O. Kapp}

REGINALD OTto KAPP, professor emeritus of electrical engineering in the University of London, died suddenly on February 20 at the age of 80 , four days after the death of his wife.

Kapp was born at Brentwood in 1885. After early education in Germany, he graduated in electrical engineering at the University of Birmingham, where his father, Prof. Gisbert Kapp, was head of the department. $\mathrm{He}$ then spent four years with Messrs. Brown Boveri in Baden, Switzerland, working on the development of electric traction. In 1913 he returned to Britain to join the staff of Messrs. Kennedy and Donkin, engineering consultants, but his new work was soon interrupted by the outbreak of the First World War in which he served with the Royal Engineers in Salonika and elsewhere.

After the War, Kapp returned to consultancy and, under Sir John Kennedy, began detailed studies of electrical power supplies and demands in Britain. These studies provided load forecasts and financial estimates which formed the technical basis of the Electricity Act, 1926, the legal instrument which established the grid system. The grid encouraged an increase in the size of generators, and Kapp worked on the associnted design and switching problems. The integration of power generating systems also aroused an early interest in the economic and technical advantages of standardization.

In 1935 Kapp was appointed to the Pender ehair of electrical engineering at University College, London. At the beginning of the Second World War, the College departments were evacuated to other universities, and Kapp, as Dean of the Faculty of Engineering, went with the engineering departments to Swansea. On their return to London, he was mainly concerned with the post-war rehabilitation of his department.

In 1950 Kapp reached the academic retiring age of sixty-five but, still full of vitality, returned to parttime consultancy with his former employers. He was chairman of a committee appointed by British Railways to reduce inductive interference between railway telecommunications and power lines. $\mathrm{He}$ also worked on energy storage by compressed air and on tidal systems as sources of power. As he had taken advantage of his early training on the Continent to equip himself as a linguisthis German, Italian and French were impeccablehe was much in demand as a chairman at international conferences. His linguistic abilities combined with his interest in standardization, of terminology as well as of equipment, led him to the chairmanship of committees of the International Standards Organization and the International Electrotechnical Commission as well as of the British Standards Institution. Consultancy work 